\title{
Garget Preventive Measures of Recipient Cows
}

\author{
Tatyana V. ZUBOVA \\ Ph.D. (in Biology) \\ Professor \\ Department of Zootechnics \\ Faculty of Livestock \\ Federal State Budgetary Educational Institution of Higher Education \\ Kuzbass State Agricultural Academy \\ 5, Markovtseva Str., Kemerovo, 650056, the Russian Federation \\ Vladimir A. PLESHKOV \\ Ph.D. (in Agriculture) \\ Associate Professor \\ Department of Animal Breeding and Genetics \\ Faculty of Zootechnics \\ Federal State Budgetary Educational Institution of Higher Education \\ Kuzbass State Agricultural Academy \\ 5, Markovtseva Str., Kemerovo, 650056, the Russian Federation
Oksana V. SMOLOVSKAYA
Ph.D. (in Biology)
Associate Professor
Department of Zootechnics
Faculty of Livestock \\ Federal State Budgetary Educational Institution of Higher Education \\ Kuzbass State Agricultural Academy \\ 5, Markovtseva Str., Kemerovo, 650056, the Russian Federation
}

\begin{abstract}
This article presents the results of the experiment to establish the effectiveness of electrostimulation with the DiaDENCE-T device in biologically active zones of breast cows-recipients to prevent mastitis. The evaluation was carried out by determination of somatic cells in milk in control and experimental groups, as well as analysis of milk productive indices at the beginning and at the end of the experiment. During the whole experiment in the experimental group of cows-recipients a stable number of somatic cells was noted, which is within the limits of norm (in cows of blackmotley breed the normal content of somatic cells up to 400 thousand/cm3), while in cows of control group since the beginning of the experiment the content of somatic cells increased by $114 \%$ and made up 784.2 thous $/ \mathrm{cm}^{3}$. The mass fraction of fat and protein in the control group was found to decrease by $19 \%$ and $5 \%$ due to the presence of subclinical mastitis in cows. In the experimental groups, the mass fraction of fat and protein was within normal limits. The control group of animals recorded an increase in white blood cell count at the end of the experiment of $12.33 \times 10^{9} / 1$, which was $36 \%$ higher than before the experiment, indicating the beginning of mastitis development. The


leukocyte content of the experimental group remained virtually unchanged and within the generally accepted norms. The results of the experiment confirm the effectiveness of the proposed method and can be used in animal husbandry to prevent mastitis.

Keywords: cattle; recipient cow; garget; udder disease; electrostimulation.

\section{Introduction}

Increasing the productivity of cattle and the marketability of the dairy sector is of high importance among the most important directions of the livestock breeding development. The root problem in the development of cattle breeding is the presence of a healthy herd on farms. For high quality milk production, a healthy cow udder is a key factor. However, milk hygiene and udder health problems are common throughout the world. One of the reasons for culling cows from the herd is to detect untreated mastitis or its consequences. Huge economic losses from mastitis are due to the loss of milk, waste of money on treatment and prevention of mastitis, and premature culling (Baryshev, 2016; Wojtenko, 2013; Bardhan, 2013; Steeneveld, Hogeveen, Barkema, 2008).

\section{Literature Review}

Mastitis is a complex disease, which is manifested by inflammation of udder tissue. Inflammation of udder in cows is noted in all physiological periods and processes of functional activity. The disease may originate under the influence of a variety of factors, the main of which include a decrease in the body's resistance, violation of milking technology, the penetration of microorganisms through the teat canal, with injuries to the teats and skin of the udder, retention of the posterior, etc. (Tuyakova, 2014; Bhutto, 2010; Fasulkov, 2012; Mukherjee, 2010).

In the course of the disease, the nature of the inflammatory process and the basic characteristics of mastitis are divided into subclinical and clinical mastitis. Subclinical mastitis is registered 5-10 times more frequently than clinical mastitis. Subclinical mastitis is specifically affected by individual groups of alveoli or udder parenchyma lobes. The incidence of mastitis varies between 19-23\%, with a ratio of clinically expressed and latent mastitis of 1:3-1:7 (Butrakov, 2014; Hiitiö, 2017; Kurjogi, Kaliwal, 2014; Memon, Javed, et al., 2012).

In livestock farms, 25.5-58.9\% of animals suffer from mastitis annually. And the form of subclinical mastitis is noted in $31.9 \%$ of cows, and the clinical form was found in $7.5 \%$ of cows. The frequency of manifestation of the form of subclinical mastitis prevails over clinical mastitis, and in $20-30 \%$ of cases subclinical mastitis is further transformed into the clinical form. The time interval of transition from one form to another and up to the moment of its detection may vary from several weeks to several months. The difficulty in detecting subclinical mastitis in time is that the 
disease is not clearly symptomatic. To prevent the development of clinical mastitis and atrophy of udder lobe, it is necessary to diagnose and treat subclinical mastitis in time. Despite the seriousness of the disease, subclinical mastitis is rarely detected on dairy farms and farms (Butrakov, 2014; Kayitsinga, 2017; Levison, Miller-Cushon, Tucker, Bergeron, Leslie, Barkema, et al., 2016; Sarba, Tola, 2017).

The World Organisation for Animal Health reports that mastitis damage far exceeds all cow diseases combined. Every year, more than $50 \%$ of the world's herd suffers from mastitis. It is found that if one quarter of the udder is affected, the udder milk yield is reduced by $20 \%$ and two quarters by $40 \%$, which then leads to low milk productivity (Bessonova, 2015; Bérdy, 2012; Rato, Bexiga, Florindo, Cavaco, Vilela, Santos-Sanches, 2013).

The annual total damage from mastitis in the world is estimated at $\$ 35$ billion. In the U.S. alone, about $\$ 2$ billion is spent annually on treatment and prevention of mastitis in cows, but even at such high costs as a result of subclinical mastitis cow disease the losses reach $\$ 960$ million. In Canada, mastitis cost up to $\$ 2$ billion, with the main financial loss coming from subclinical mastitis. In England, mastitis is $22 \%$ of the population - damage is estimated at 64.87 million dollars. In Germany, the rate of mastitis disease in cows reached $29.9 \%$ and the damage was estimated at $\$ 197.7$ million. The economic loss in Denmark is $\$ 20.56$ million and about 28\% of the herd suffers from mastitis. Japan's mastitis damage is estimated at $\$ 79.1$ million. The cost of cow mastitis activities in the Netherlands is estimated at $\$ 45.0$ million. In Poland, mastitis losses from cows are estimated at about \$90.45 million (Bardhan, 2013; Hiitiö, 2017; Kayitsinga, 2017; Levison, et al., 2016; Zadoks, Middleton, McDougall, Katholm, Schukken, 2011).

To date, preventive measures in livestock farms include a number of works. The main of such activities include organizing a group of cows prone to mastitis, providing quality feed and appropriate housing conditions, reducing stress, strict adherence to milking technology, as well as diagnosis for cow mastitis. Diagnosing subclinical mastitis is an expensive and time-consuming process that requires an udder examination by a veterinarian and special chemical tests for milk analysis (Baryshev, 2016; Perepeluk, 2012; Kurjogi, M.M., Kaliwal, 2014; Taponen, Liski, Heikkilä, Pyörälä, 2017).

Treatment of cows from mastitis conditionally divided into two large categories: medical and physiotherapeutic. The treatment of mastitis with antibiotics, sulfonamide preparations, antimastitic emulsions, suspensions and ointments is classified as medication. Physiotherapeutic methods of treatment of mastitis include paraffin therapy, ultraviolet irradiation, ultrasound treatment, laser treatment as well as UHF and SHF treatment (Butrakov, 2014; Bérdy, 2012; Chen, 2015; 
Fiordalisi, 2016; Petrelli, Orsomando, Sorci, Maggi, Ranjbarian, Biapa Nya, Petrelli, Vitali, Lupidi, Quassinti, Bramucci, Hofer, Cappellacci, 2016).

Currently, disinfectants are used to prevent mastitis in cows that cannot be considered safe due to their chemical composition. It is not uncommon for animals to get skin irritations, inflammations etc. after treatment with such preparations (Wojtenko, 2013; Kayitsinga, 2017; Memon, Javed, et al., 2012).

Antibiotics used as a substitute for disinfectants are hard to call a good alternative. Often antibiotics are injected in large quantities, the residues of which are then found in milk. Also the haphazard use of antibiotics in the treatment of mastitis contributed to the development of antibiotic resistance, and as a result, reduced treatment efficiency due to the formation of drug-resistant strains of microorganisms. In addition, it has been established that antibiotic drugs can have a negative impact on animal immunological reactivity, which may explain the lack of effectiveness of treatment (Baryshev, 2016; Perepeluk, 2012; Bérdy, 2012; Rato, et al., 2013; Taponen, et al., 2017).

In cattle embryo transplantology, mastitis is also ranked not least. It is very important that donor and recipient cows are healthy animals. Otherwise, there is a high probability of unhealthy calves or premature termination of pregnancy, which again leads to high economic losses.

According to article VI. of the rules of cattle keeping for the purposes of its reproduction, rearing and sale (order of the Ministry of Agriculture of the Russian Federation, order No. 551 of December 13, 2016) the following requirements for obligatory preventive measures and diagnostic tests of cattle must be observed:

- all livestock used for embryo transfer should be diagnosed, vaccinated and treated against infectious diseases in accordance with the anti-epizootic action plan developed for the enterprise;

- it is necessary for specialists of veterinary service to carry out periodic medical examination of animals at the enterprise;

- the animals are examined every time they are transferred from one physiological group to another. Clinical and laboratory tests of animal blood are carried out at the dispensary;

- based on the results of clinical and laboratory research, a number of measures are taken to prevent and treat metabolic disorders and to increase the natural resistance of the animal organism;

- specialists of the veterinary service of the farm conduct preventive inspection of hooves, their treatment by running groups of cows through baths with disinfectant solution, in addition, it is obligatory to clean and prune hooves at least 2 times a year; 
- mastitis udder assessment is required.

To prevent mastitis in cows-recipients it is recommended to electrostimulate the biologically active zones of the mammary gland with the device DiaDENCE-T for 4 minutes at the frequency of $10 \div 15 \mathrm{~Hz}$, the procedure is carried out daily for 10 days.

In this regard, it is important to strengthen preventive measures against mastitis and prevent its transition to clinical status. Treatment of biologically active zones (BAZ) of mammary gland of cows by electrostimulation is considered to be the safest, which has no negative impact either on the animal body or on milk received from it.

\section{Methods}

Scientific researches have been carried out on the basis of dairy farm "Mikhailovskoye" of Prokopievsky district of Kemerovo region. In order to prevent the development of such a dangerous disease in selected cows-recipients it is proposed to use the device DiaDENCE-T, designed to provide general regulatory impact on the physiological systems of the body and to treat functional disorders in a wide range of diseases. Dynamic electroneurostimulation is performed by impulses of electric current on biologically active zones of animal organism.

To confirm the effectiveness of the proposed method, a number of factors were observed in the experiment, increasing the probability of mastitis infection in cows-recipients up to $47 \%$ :

1) age of cows-recipients - 4 years;

2) lactation stage - 10th day after calving;

3) keeping conditions (heat, humidity, draughts).

The study was conducted on selected recipient cows divided into three groups:

Control group ( $n=6)$ - cows that were not exposed to the device on breast biologically active zones (BAZ) and other prophylactic procedures to prevent mastitis.

I test group - biologically active areas of the breast of cow recipients were treated with the device DiaDENCE-T for 4 minutes at a frequency of $10 \div 15 \mathrm{~Hz}$. The device was moved from the udder base to each nipple (1 BAZ 1 minute exposure time).

II test group - biologically active areas of the breast of cow recipients were treated with the DiaDENCE-T device for 8 minutes at $20 \div 30 \mathrm{~Hz}$. The device was moved from the udder base to each nipple (1 BAZ 1 minute exposure time).

Electric stimulation was carried out daily for 10 days (according to the instructions, to the device). 
Animals of all groups were in the same conditions of feeding and keeping, at the same lactation stages.

Before the experiment, a general examination of the selected cows was carried out: body temperature, cardiac rate and frequency of breathing were measured (Table 1). After processing with DiaDENCE-T, these indicators were measured once again to confirm the innocuousness of the proposed method.

Table 1. Physiological indices of cows at start and end of experience

\begin{tabular}{lllllll} 
& \multicolumn{2}{c}{ Body temperature, ${ }^{\circ} \mathbf{C}$} & \multicolumn{2}{c}{ Cardiac rate, per minute } & \multicolumn{2}{c}{$\begin{array}{c}\text { Frequency of breathing, per } \\
\text { minute }\end{array}$} \\
\cline { 2 - 6 } Group & $\begin{array}{c}\text { Beginning of } \\
\text { the } \\
\text { experiment }\end{array}$ & $\begin{array}{c}\text { End of the } \\
\text { experiment }\end{array}$ & $\begin{array}{c}\text { Beginning } \\
\text { of the } \\
\text { experiment }\end{array}$ & $\begin{array}{c}\text { End of the } \\
\text { experiment }\end{array}$ & $\begin{array}{c}\text { Beginning of } \\
\text { the experiment }\end{array}$ & $\begin{array}{c}\text { End of the } \\
\text { experiment }\end{array}$ \\
\hline Control & $38.4 \pm 0.32$ & $38.3 \pm 0.62$ & $75.5 \pm 0.57$ & $79.1 \pm 0.64$ & $20.8 \pm 0.49$ & $21.8 \pm 0.59$ \\
\hline I test group & $39.1 \pm 0.24$ & $38.8 \pm 0.48$ & $78.3 \pm 0.59$ & $78.4 \pm 0.58$ & $20.5 \pm 0.56$ & $21.5 \pm 0.53$ \\
\hline II test group & $38.6 \pm 0.41$ & $38.8 \pm 0.34$ & $77.8 \pm 0.48$ & $76.7 \pm 0.55$ & $21.6 \pm 0.58$ & $20.6 \pm 0.51$
\end{tabular}

As can be seen from Table 1, there were no differences in physiological indices in cows before and after the experience, which indicates that the DiaDENCE-T device is harmless.

\section{Results}

The efficacy of electrical stimulation with the DiaDENCE-T device in the biologically active zones of the mammary gland of the cow receivers was evaluated by determining somatic cells in the milk in the control and experimental groups, as well as by analyzing milk productivity at the beginning and end of the experiment (on day 11) (Figure 1, Table 1).

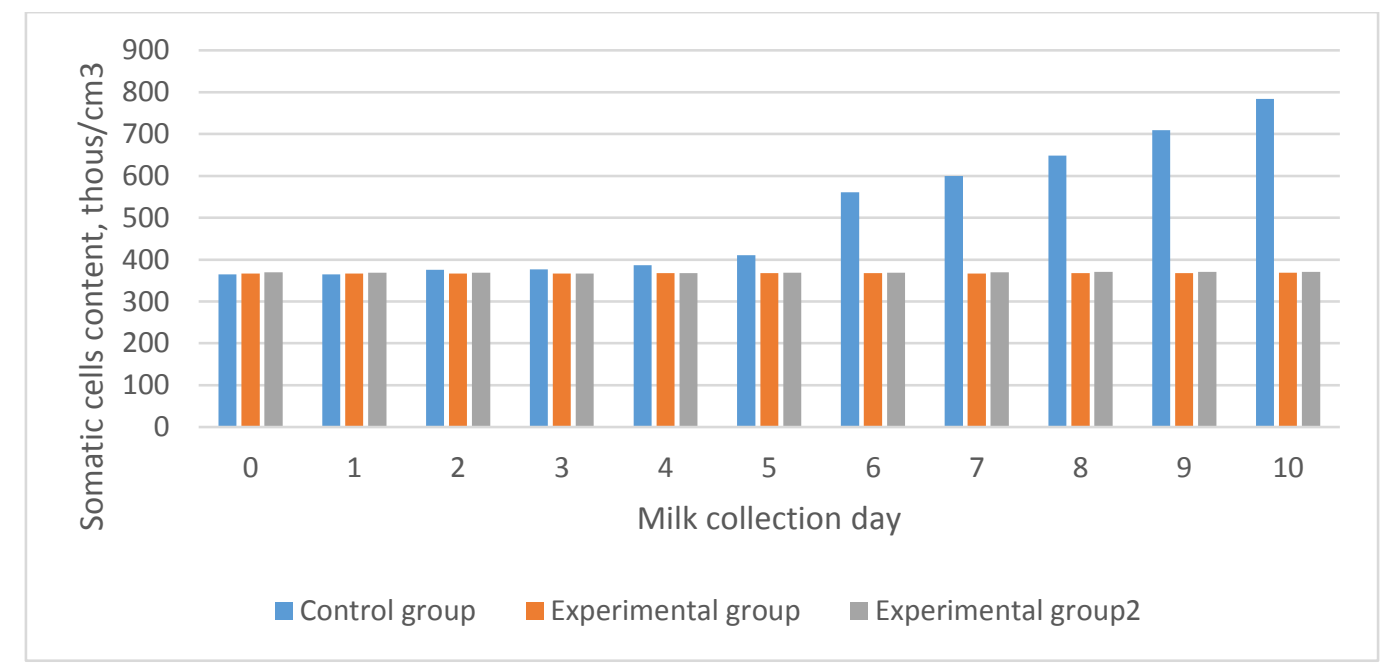

Figure 1. Efficiency of mastitis prevention with DiaDENCE-T device at various parameters 
Physiological norm of somatic cells content in milk is considered to be from 100 to 500 thous $/ \mathrm{cm}^{3}$ (normal somatic cells content up to 400 thous $/ \mathrm{cm}^{3}$ in cows of black and motley breed). As it can be seen from Figure 6, after 10 days in unfavorable conditions in cows of the control group the content of somatic cells in milk increased (by $114 \%$ and made up 784.2 thous $/ \mathrm{cm}^{3}$ ), which indicates the development of inflammatory processes (mastitis) in cows.

During the whole experiment, a stable number of somatic cells was observed in the experimental group of cows-recipients, which is within the normal range. Thus, electrostimulation of biologically active zones of the breast with DiaDENCE-T device has a preventive effect and prevents the development of inflammatory process (mastitis) (Table 2).

Table 2. Milk indices after electrostimulation with DiaDENCE-T device

\begin{tabular}{lcccccc} 
& \multicolumn{2}{c}{ Control group } & \multicolumn{2}{c}{ I test group } & \multicolumn{2}{c}{ II test group } \\
\cline { 2 - 7 } Indices & $\begin{array}{c}\text { Beginning of } \\
\text { the } \\
\text { experiment }\end{array}$ & $\begin{array}{c}\text { End of the } \\
\text { experiment }\end{array}$ & $\begin{array}{c}\text { Beginning of } \\
\text { the } \\
\text { experiment }\end{array}$ & $\begin{array}{c}\text { End of the } \\
\text { experiment }\end{array}$ & $\begin{array}{c}\text { Beginning of } \\
\text { the } \\
\text { experiment }\end{array}$ & $\begin{array}{c}\text { End of the } \\
\text { experiment }\end{array}$ \\
\hline Fat, \% & $3.70 \pm 0.18$ & $3.00 \pm 0.15$ & $3.70 \pm 0.18$ & $3.70 \pm 0.18$ & $3.68 \pm 0.18$ & $3.65 \pm 0.18$ \\
\hline Protein, \% & $3.35 \pm 0.16$ & $3.18 \pm 0.15$ & $3.35 \pm 0.16$ & $3.33 \pm 0.16$ & $3.37 \pm 0.16$ & $3.40 \pm 0.17$ \\
\hline $\begin{array}{l}\text { Specific } \\
\text { density, } \\
\mathrm{kg} / \mathrm{m}^{2}\end{array}$ & $29.65 \pm 1.48$ & $29.54 \pm 1.47$ & $29.67 \pm 1.48$ & $29.65 \pm 1.48$ & $29.67 \pm 1.48$ & $30.10 \pm 1.51$
\end{tabular}

The reduction of mass proportions of fat and protein in the control group by $19 \%$ and $5 \%$ is also due to the presence of subclinical mastitis in cows. In I and II experimental groups, the mass fraction of fat and protein was within the norm, which also confirms the effectiveness of the proposed method.

\section{Discussion}

According to the obtained results it was decided that it is not rational to use the method of breast treatment in the II experimental group. The method assumes the choice of higher frequency of electrostimulation $(20 \div 30 \mathrm{~Hz})$ and longer time of treatment (8 minutes), while in the $1 \mathrm{st}$ experimental group the same quality parameters of milk are achieved at 4 minutes of electrostimulation treatment $10 \div 15 \mathrm{~Hz}$.

The impact of the proposed method of treating the breast glands of cow donors can also be determined by blood morphology. The results of the study are presented in Table 3. 
Table 3. Morphological parameters of blood of cows-recipients before and after treatment with DiaDENCE-T

\begin{tabular}{lcccc}
\multicolumn{1}{c}{ Indices } & \multicolumn{3}{c}{ Index value } \\
\cline { 2 - 5 } & \multicolumn{2}{c}{ Control group } & \multicolumn{2}{c}{ I test group } \\
\cline { 2 - 5 } & $\begin{array}{c}\text { Beginning of the } \\
\text { experiment }\end{array}$ & $\begin{array}{c}\text { End of the } \\
\text { experiment }\end{array}$ & $\begin{array}{c}\text { Beginning of the } \\
\text { experiment }\end{array}$ & $\begin{array}{c}\text { End of the } \\
\text { experiment }\end{array}$ \\
\hline Erythrocytes, $10^{12} / 1$ & 6.63 & 7.38 & 6.92 & 7.14 \\
\hline Hb, g/l & 120.15 & 103.45 & 117.86 & 118.12 \\
\hline Leucocytes, $10^{9} / 1$ & 9.05 & 12.33 & 8.75 & 447.00 \\
\hline Thrombocytes, $10^{9} / 1$ & 450.00 & 441.22 & & - \\
\hline & & Leukogram, $\%$ & - & 5.0 \\
\hline Basophils & - & - & 4.0 & 39.0 \\
\hline Eosinophils & 4.0 & 5.0 & 40.0 & 51.0 \\
\hline Neutrophils & 39.0 & 38.0 & 51.0 & 5.0
\end{tabular}

As can be seen from the data obtained, the number of erythrocytes increased by $3.2 \%$ after 10 days of electrostimulation with DiaDENCE-T, the values of leukocyte formula remained practically unchanged.

The most important indicators are the number of leukocytes to blood of cow receivers in control and experimental groups. The control group showed an increase in white blood cell count at the end of the experiment of $12.33 \times 10^{9} / 1$, which is $36 \%$ more than before the experiment. Such a sharp increase in white blood cells indicates the onset of inflammatory processes in the body, in particular the development of mastitis. In the experimental group the content of leukocytes remained practically unchanged and was within the generally accepted norms.

\section{Conclusion}

Thus, one of the most common diseases is mastitis in cows. Subclinical mastitis is considered to be one of the most common and dangerous diseases, because it has no visible signs and is difficult to determine in the early stages of development. Every year, farms spend huge sums of money on activities aimed at diagnosis, prevention and treatment of mastitis, which in turn leads to higher prices of products offered in the market. The presented results confirm efficiency of the offered method and can be recommended to farms for prevention of mastitis at cows-recipients that will allow reducing economic losses in connection with reception of a healthy herd.

\section{Acknowledgements}

This article is written under terms of the agreement with the Ministry of Education and Science of the Russian Federation № 05.607.21.0208 "Development of genome editing technology for the 
IV International Scientific and Practical Conference "Modern S\&T Equipments and Problems in Agriculture"

reproduction of high-value breeding dairy cattle resistant to leukemia virus" unique identifier agreement RFMEFI60718X0208.

\section{References}

Bardhan, D. (2013). Estimates of economic losses due to clinical mastitis in organized dairy farms. Indian Journal of Dairy Science, 66(2), 168-172.

Baryshev, V.A. (2016). Aspects of antibiotics problem solving in veterinary practice. International bulletin of veterinary medicine, 1, 23-28.

Bérdy, J. (2012). Thoughts and facts about antibiotics: where we are now and where we are heading. Journal of Antibiotics, 65(8), 385-395.

Bessonova, L.P. (2015). Dairy products quality as a guarantee of competitiveness increase. Dairy industry, 4, 22-24.

Bhutto, A.L. (2010). Udder shape and teat-end lesions as potential risk factors for hih somatic cell counts and inta-mamnary infections in dairy cows. Veterinary Journal, 183(1), 63-67.

Butrakov, A.A. (2014). Udder disease prevention in cows and milk quality improvement with application of the new domestic preparations. Veterinary Medicine, 3, 40-41.

Chen, X. (2015). Ethanol extract of Sanguisorba officinalis L. inhibits biofilm formation of methicillin-resistant Staphylococcus aureus in an ica-dependent manner. Journal of Dairy Science, 98(12), 8486-91.

Fasulkov, I.R. (2012). Ultrasonography of the mammary gland in ruminants: a review. Bulgarian Journal of Veterinary Medicine, 1, 1-12.

Fiordalisi, S.A. (2016). The effects of Brazilian propolis on etiological agents of mastitis and the viability of bovine mammary gland explants. Journal of Dairy Science, 99(3), 2308-2318.

Hiitiö, H. (2017). Prevalence of subclinical mastitis in Finnish dairy cows: changes during recent decades and impact of cow and herd factors. Acta Veterinaria Scandinavica, 59(1), 22.

Kayitsinga, J. (2017). Antimicrobial treatment of clinical mastitis in the eastern United States: The influence of dairy farmers' mastitis management and treatment behavior and attitudes. Journal of Dairy Science, 100(2), 1388-1407.

Kurjogi, M.M., Kaliwal, B.B. (2014). Epidemiology of bovine mastitis in cows of Dharwad District. International Scholarly Research Notices, 2014, 1-9. 
Levison, L.J., Miller-Cushon, E.K., Tucker, A.L., Bergeron, R., Leslie, K.E., Barkema, H.W., et al. (2016). Incidence rate of pathogen-specific clinical mastitis on conventional and organic Canadian dairy farms. Journal of Dairy Science, 99, 1341-1350.

Memon, J., Javed, J., et al. (2012). Molecular characterization and antimicrobial sensitivity of pathogens from sub-clinical and clinical mastitis in Eastern China. Pakistan Veterinary Journal, 33, 170-174.

Mukherjee, R. (2010). Evaluation of mammary gland immunity and therapeutic potential of Tinospora cordifolia against bovine subclinical mastitis. Tropical Animal Health and Production, 42(4), 645-651.

Perepeluk, A. (2012). The treatment of mastitis can be profitable. We treat mastitis without antibiotics. AIC Expert, 4, 42-44.

Petrelli, R., Orsomando, G., Sorci, L., Maggi, F., Ranjbarian, F., Biapa Nya, P.C., Petrelli, D., Vitali, L.A., Lupidi, G., Quassinti, L., Bramucci, M., Hofer, A., Cappellacci, L. (2016). Biological Activities of the Essential Oil from Erigeron floribundus. Molecules, 21, 1065.

Rato, M.G., Bexiga, R., Florindo, C., Cavaco, L.M., Vilela, C.L., Santos-Sanches, I. (2013). Antimicrobial resistance and molecular epidemiology of Streptococci from bovine mastitis. Veterinary Microbiology, 161, 286-294.

Sarba, E.J., Tola, G.K. (2017). Cross-sectional study on bovine mastitis and its associated risk factors in Ambo district of West Shewa zone, Oromia, Ethiopia. Veterinary World, 10(4), 398-402.

Steeneveld, W., Hogeveen, H., Barkema, H.W. (2008). The Influence of Cow Factors on the Incidence of Clinical Mastitis in Dairy Cows. Journal of Dairy Science, 91, 1391-1402.

Taponen, S., Liski, E., Heikkilä, A.M., Pyörälä, S. (2017). Factors associated with intramammary infection in dairy cows caused by coagulase-negative staphylococci, Staphylococcus aureus, Streptococcus uberis, Streptococcus dysgalactiae, Corynebacterium bovis and Escherichia coli. Journal of Dairy Science, 100, 493-503.

Tuyakova, R.K. (2014). Species composition and sensitivity to antibiotics of the microflora isolated from the milk of the cow mastitis patients. Veterinary Medicine, 8, 41-44.

Wojtenko L.G. (2013). Mastitis. Diagnosis. Methods of treatment. Veterinary Pathology, 4(46), 9-13. 
IV International Scientific and Practical Conference "Modern S\&T Equipments and Problems in Agriculture"

Zadoks, R.N., Middleton, J.R., McDougall, S., Katholm, J., Schukken, Y.H. (2011). Molecular epidemiology of mastitis pathogens of dairy cattle and comparative relevance to humans. Journal of Mammary Gland Biology and Neoplasia, 16(4), 357-372. 